\title{
The Influence of Social Capital on Small Micro-manufacturing Venture in China
}

\author{
Shaoxia Zhao* and Yongming Zhu \\ Administrative Engineering College, Zhengzhou University, Zhengzhou, China \\ *Corresponding author: 1358804759@qq.com
}

\begin{abstract}
In recent years, because of the government's policy support and the scholars' attention, the small micro-manufacturing industry has been developing rapidly. However, due to small scale, limited financial resources, imperfect management and other constraints, small micro-manufacturing survival rate is relatively low. Scholars have been actively exploring the factors that affect micro-manufacturing entrepreneurship, and agreed that social capital has an important impact on micro-manufacturing industry. This paper analyzes the effects of social capital on the small and micro-manufacturing entrepreneurship from the perspective of structural capital, relational capital and cognitive capital by collecting relevant data, using questionnaire survey, structural equation method, and other empirical research. The results show that the three dimensions of social capital have positive effects on small and micro-manufacturing entrepreneurial behaviour. The results provide theoretical basis for small micro-manufacturing enterprises, and have a certain reference value for the follow-up study of small micro-manufacturing industry.
\end{abstract}

\section{Introduction}

Since the reform and opening up, China's small micro-manufacturing industry has gone through a process from small to large, from small to large. At present, the research on the micro-micro-manufacturing industry has aroused extensive attention in the academic circles. But so far, Small micro-manufacturing industry researches, more focused on the study of micro-manufacturing content, features, etc., are rarely involved in small micro-manufacturing entrepreneurial issues (Han Dongping, 2012 [1]). In the western academic circles, many scholars have studied the entrepreneurial behaviour of enterprises. Since the 1980s, social capital theory has been used in entrepreneurial research, and has been gradually introduced into the analysis of entrepreneurial behaviour (Stam, 2008 [2]). What is the role of social capital in entrepreneurship? To what extent? In what ways? None of these questions has been given a very rigorous conclusion. Therefore, the purpose of this paper is to study the entrepreneurial behaviour of small micro-manufacturing industry from the perspective of social capital, so as to reveal the impact of social capital on small and micro-manufacturing entrepreneurship.

\section{Literature review}

\subsection{Social capital}

The concept of "Corporate Social Capital" was first proposed in 1985 by the French scholar Pierre Bourdiet [3]. Social capital is increasingly concerned by many disciplines. Koka and Prescott (2000) [4] extended the study of social capital to the corporate level, making the academic community began to pay attention to corporate social capital [4]. At the same time, companies are beginning to realize the importance of the accumulation of social capital. More research has been done on the connotation and measurement of corporate social capital: China's scholar Qiu Zhongning (2000) divides the social capital of enterprises into horizontal, vertical and social relations, and points out that the enterprise can obtain the necessary resources by using these three links [5]; Westlund (2003) divides the social capital of an enterprise into internal and external social capital, in which the relationship between managers and employees is the internal social capital of an enterprise, and the resources related to the market and the environment are the external social capital of the firm[6]; Lin Yun (2011) divides the enterprise capital into cognitive dimension, relation dimension and structural dimension, and analyzes the influence of each dimension on enterprise innovation ability[7].

\subsection{Small micro-manufacturing industry}

(C) The Authors, published by EDP Sciences. This is an open access article distributed under the terms of the Creative Commons Attribution License 4.0 (http://creativecommons.org/licenses/by/4.0/). 
Small micro-manufacturing industry refers to the number of employees is less than 10 people, a high degree of unity of property rights and management rights, products (services) single, small-scale enterprise organizations. Foreign theoretical circles have realized the prominent role of microenterprises in information technology. In order to facilitate research, the European Commission united the definition of standards in $19 \%$ of the year, with the number of employees ranging from 1 to 9 as very small $(\mathrm{Li}, 2012)$ [8].

China's theoretical circles of small micro-manufacturing research scattered in the study of small businesses. In China's current economic policy is not a small micro-manufacturing industry, the habit of small and micro enterprises as "self-employed." People only concerned about how large enterprises to enter the world's top 500 enterprises, "grasping big and small" from a certain perspective reflects the fate of the small micro-manufacturing disregard, so that people set up small micro-manufacturing power is inhibited, and further, Large-scale enterprises have lost their cooperation network composed of small micro-manufacturing and so on. Large-scale enterprises are in the cycle of self-service, and the returns of scale returns are not obvious (Zhou Ronghua, 2016) [9].

\subsection{Research assumptions}

China is in the economic transition period, social capital plays an important role in the development of enterprises. First, the enterprise can obtain the necessary information and resources through social capital. Corporate social capital can not only influence the transmission and application of market information in social networks, but also help enterprises to obtain important external environment information, and provide the basis for enterprise strategy formulation, and is an important source for enterprises to obtain specific resources or related policy support [11]. Second, corporate social capital helps enterprises and their network members to establish a trust mechanism to form a good environment for cooperation. Compared with the low degree of social capital accumulation, enterprises with rich social capital have higher credit level and can strengthen the relationship between enterprises and the stakeholders such as suppliers and sellers, so as to provide the necessary external environment support. Finally, corporate social capital can enhance the cohesion of enterprises and their own resources of creativity. Internal social capital can link different departments of enterprises, strengthen trust among members, and promote organizational goals to achieve agreement [12], for small micro-manufacturing venture to provide the necessary internal environmental support. Based on the above analysis, this paper proposes the following assumptions:

H1: The number of small-scale entrepreneurial social interactions positively affects entrepreneurial behaviour

$\mathrm{H} 2$ : The social capital on the relationship dimension has a positive effect on small and micro manufacturing entrepreneurial behaviour

H3: The cognitive capital dimension has a positive effect on small and micro manufacturing entrepreneurial behaviour

\section{Research and design}

\subsection{Research methods and data processing}

In this study, a questionnaire survey was used, and the contents of the questionnaire were filled in by the founders of small and micro-manufacturing industries. This questionnaire is divided into two parts: small micro-manufacturing entrepreneur personal and small micro-manufacturing basic information, small micro-manufacturing entrepreneur social capital measurement of three dimensions.

The first is to investigate the basic situation of small and micro-manufacturing entrepreneurs and small and micro-manufacturing industry, namely: the name of the enterprise, the industry, the nature of the enterprise, the registered capital of enterprises, the number of employees and enterprises set up years. The social capital of small and small manufacturing entrepreneurs is divided into three dimensions: structural dimension, relationship dimension and cognitive dimension, followed by measurement of the four aspects of small and micro manufacturing entrepreneurial behaviour. The measurement design of this questionnaire is based on Vesa Puhakka (2006) [13] studied the measurement scale. Micro-manufacturing entrepreneurial behaviour is divided into four dimensions: access to business knowledge, competitive scrutiny, forward-looking search and innovative behaviour.

\subsection{Variable selection}

\subsubsection{An interpreted variable}

Micro-manufacturing entrepreneurial behaviour from four aspects to show, namely: access to business knowledge, competitive scrutiny, forward-looking search and innovative behaviour. First of all, access to business knowledge behaviour refers to the behaviour of the general social interaction and entrepreneur's personal relationship behaviour, the acquisition of the customer, technology, products, finance and scientific research information into the business knowledge behaviour. Second, competitive scrutiny includes the observation of market competition, the search for market vulnerabilities, and the formulation of competitive strategies and tactics. Third, forward-looking search 
refers to behaviour by understanding the external environment of the enterprise, predicting the future competitive situation of the enterprise, evaluating the behaviour of the enterprise resource situation, and observing and forecasting the development trend of the industry and enterprise. Fourth, innovation behaviour refers to the act of generating the innovative thinking and implementing the innovative practice, questioning the behavioural way and mode of thinking, and seeking to change the behaviour.

\subsubsection{Explain the variables}

At present, in a number of theories on social capital, Ghoshal (1998) gave a more complete measure. His theory represents social capital in three dimensions: structure, relationship and cognition.

The structural dimension of social capital measures the size of the entrepreneurial circle, that is, the number of social contacts between entrepreneurs and their social relations. The more social interaction, the greater the index of social capital structure dimensions. The relationship dimension of social capital measures the degree to which the relationship between entrepreneurs and their social relationships is close, that is, the frequency with which the entrepreneur interacts with his circle. The higher the frequency, the greater the degree of tightness, the greater the measure of the relationship dimension. The cognitive dimension of social capital measures the emotional loyalty between the entrepreneur and their relationship circle. The more the relationship circle provides, the more interdependent the team member in the entrepreneurial team. The more support, the larger the measure of cognitive dimension.

\subsubsection{Control variables}

There are many factors that affect the micro-manufacturing entrepreneurship. Taking into account the individual differences of small and small manufacturing entrepreneurs and their access to and use of social capital, this paper selects the age $(N L)$, gender $(\mathrm{XB})$, and educational level $(J Y)$ of the small micro-manufacturing entrepreneur as the control variable. The variables and definitions as shown in Table 1:

Table 1. Study variables and definitions

\begin{tabular}{|c|c|c|c|}
\hline & $\begin{array}{c}\text { The variable } \\
\text { name }\end{array}$ & $\begin{array}{l}\text { Variable } \\
\text { symbol }\end{array}$ & $\begin{array}{c}\text { Variable } \\
\text { definition }\end{array}$ \\
\hline $\begin{array}{l}\text { Explained } \\
\text { variable }\end{array}$ & $\begin{array}{c}\text { Small micro } \\
\text { manufacturing } \\
\text { entrepreneuria } \\
1 \text { behaviour }\end{array}$ & $\begin{array}{c}\mathrm{JH} \\
\mathrm{JJ} \\
\mathrm{JQ} \\
\mathrm{JC}\end{array}$ & $\begin{array}{c}\text { Gaining business } \\
\text { knowledge, } \\
\text { Jcompetitive } \\
\text { scrutiny, } \\
\text { forward-looking } \\
\text { search and } \\
\text { Innovation } \\
\text { behaviour }\end{array}$ \\
\hline $\begin{array}{l}\text { Explanatory } \\
\text { variables }\end{array}$ & Social capital & $\begin{array}{l}\text { SJ } \\
\text { SG } \\
\text { SR }\end{array}$ & $\begin{array}{l}\text { Structural capital, } \\
\text { relational capital, } \\
\text { cognitive capital }\end{array}$ \\
\hline \multirow{3}{*}{$\begin{array}{c}\text { Control } \\
\text { variables }\end{array}$} & $\begin{array}{c}\text { Entrepreneur } \\
\text { Age }\end{array}$ & $\mathrm{NL}$ & $\begin{array}{c}\text { The questionnaire } \\
\text { was informed }\end{array}$ \\
\hline & $\begin{array}{l}\text { Entrepreneur } \\
\text { gender }\end{array}$ & $\mathrm{XB}$ & $\begin{array}{c}\text { The questionnaire } \\
\text { was informed }\end{array}$ \\
\hline & $\begin{array}{l}\text { Entrepreneur } \\
\text { education } \\
\text { level }\end{array}$ & JY & $\begin{array}{c}\text { The questionnaire } \\
\text { was informed }\end{array}$ \\
\hline
\end{tabular}

\section{Structural equation models}

$$
\begin{gathered}
S J=j_{1} S 1+j_{2} S J 2+j_{3} S J 3+j_{4} S J 4+e_{1} \\
S G=g_{1} S G 5+g_{2} S G 6+g_{3} S G 7+e_{2} \\
S R=r_{1} S R 8+r_{2} 2 S R 9+e_{3} \\
J H=h_{1} J H 1+h_{2} J H 2+h_{3} J H 3+h_{4} J H 4+e_{4} \\
J J=j_{1} J J 5+j_{2} J J 6+j_{3} J J 7+e_{5}
\end{gathered}
$$




$$
\begin{gathered}
J Q=q_{1} J Q 8+q_{2} J Q 9+q_{3} J Q 10+e_{6} \\
J C=c_{1} J C 11+c_{2} J C 2+e 7 \\
M_{1} J H+m_{2} J J+=3 J Q+m_{4} J C=n_{1} S J+n_{2} S G+n_{3} S R+n_{4} N L+n_{5} X B+n_{6} J Y+e_{9}
\end{gathered}
$$

$J H, J Q, J J, J C$ are the four kinds of behaviours of small and micro-manufacturing entrepreneurial social capital structure, In the acquisition of business knowledge, competitive scrutiny, prospective search, and innovation behaviour represent potential variables. In addition, the years of establishment, the age of entrepreneurs, the degree of education $(J Y)$ are taken as the control variables.

\section{Empirical analyses}

\subsection{Sample analysis}

In order to ensure the effectiveness of the study, selected subjects must meet the following conditions: First, the entrepreneurs are the founder of business people who have achieved the process of enterprise entrepreneurs from scratch. Second, the enterprise must be a small micro-manufacturing, and survival time of 2 years. A total of 880 questionnaires were sent out and 743 were returned. Among them, the effective questionnaire is 650 copies. The effective recovery rate was $73.86 \%$.

Using SPASS software, the reliability of the questionnaire was analysed, as shown in Table 2. Social capital and micro-manufacturing entrepreneurial behaviour of all dimensions of a value and the overall a value is higher than 0.7 , in line with the requirements of the reliability requirements ( $>0.6)$. The overall reliability and stability of the questionnaire were cantered. While the CITC values of all dimensions are greater than 0.5 , indicating that the scale

\begin{tabular}{|c|c|c|c|c|}
\hline Variables & Variable indicator & CITC & $\begin{array}{l}\text { The value of each } \\
\text { dimension (a) }\end{array}$ & $\begin{array}{l}\text { Overall value } \\
\text { (a) }\end{array}$ \\
\hline \multirow{3}{*}{ Social capital } & Structural dimension & 0.629 & 0.841 & \multirow{3}{*}{0.850} \\
\hline & Capital dimension & 0.686 & 0.865 & \\
\hline & Cognitive dimension & 0.539 & 0.869 & \\
\hline \multirow{4}{*}{$\begin{array}{c}\text { Small and micro } \\
\text { manufacturing } \\
\text { Entrepreneurial } \\
\text { behaviour }\end{array}$} & Get business knowledge & 0.541 & 0.830 & \multirow{4}{*}{0.797} \\
\hline & Competitive review & 0.556 & 0.804 & \\
\hline & Forward-looking search & 0.510 & 0.780 & \\
\hline & Innovation behaviour & 0.584 & 0.849 & \\
\hline
\end{tabular}
design project reliability is good, without removal.

Table 2. Reliability of social capital and entrepreneurial behaviour

\subsection{Hypothesis testing}

\subsubsection{Test for hypothesis $\mathrm{H1}$}

As shown in rows (2), (3), (4) and (5) of Table 3, the path coefficients of social capital on the structural dimension are all significantly positive at 0.01 level, providing data on the assumption that $\mathrm{H} 1$ is established stand by. The small number of micro-manufacturing entrepreneurial social interaction positive impact on entrepreneurial behaviour, that is, micro-manufacturing to expand the number of social contacts, can get more information to help compete in the competency to review, make the right judgments, Forward-looking issues, the more conducive to innovation. It shows that the dimension of social capital structure has positive correlation with four kinds of behaviours, namely, business knowledge acquisition, competitive examination, forward-looking search and innovation in micro-micro-manufacturing entrepreneurial behaviour.

\subsubsection{Hypothesis $\mathrm{H} 2$ test}

As shown in lines (6), (7), (8) and (9) in Table 3, the path coefficients of the social capital on the relationship dimension are all significantly positive at 0.01 level, proving that the hypothesis $\mathrm{H} 2$ holds. Entrepreneurs social relations more closely, the more can be obtained from more channels can not get or get the first time the information, 
the future of the foreseeable than others grasp more accurate. Social relations, the degree of tightening, can also be used to help entrepreneurs to form innovative thinking, mutual awareness of the enhanced collaboration, from the intrinsic to enhance the quality of entrepreneurs. It shows that there is positive correlation between the dimensions of social capital and business knowledge, competitive examination, prospective search and innovation in small and micro manufacturing entrepreneurial behaviour.

\subsubsection{Test for hypothetical $\mathrm{H3}$}

As shown in lines (10), (11), (12) and (13) in Table 3, the social capital in the cognitive capital dimension and the competitive scrutiny in the micro- and micro-manufacturing start- And there was a significant positive correlation between the level of entrepreneurial behaviour and the level of positive correlation in the level of obtaining business knowledge behaviour.

Table 3. The path coefficient table and the significance relation of the model

\begin{tabular}{|c|c|c|c|}
\hline Variable relationship & Path coefficient & T value & The number of rows \\
\hline SJ vs.JH & $0.0436^{* * *}$ & 8.259 & (2) \\
\hline SJ vs.JJ & $0.004^{* * *}$ & 4.808 & (3) \\
\hline SI vs.JQ & $0.063^{* * *}$ & 10.826 & (4) \\
\hline SJ vs.JC & $0.033^{* * *}$ & 6.847 & (5) \\
\hline SG vs.JH & $0.090^{* * *}$ & 21.946 & (6) \\
\hline SG vs.JJ & $0.068^{* * *}$ & 12.553 & (7) \\
\hline SG vs.JQ & $0.069^{* * *}$ & 12.301 & (8) \\
\hline SG vs.JC & $0.030^{* * *}$ & 6.169 & (9) \\
\hline SR vs.JH & $0.099^{*}$ & 2.325 & $(10)$ \\
\hline SR vs.JJ & $0.030^{* *}$ & 0.894 & (11) \\
\hline SR vs.JQ & $0.068^{* *}$ & 1.170 & (12) \\
\hline SR vs.JC & $0.067^{* * *}$ & 8.112 & (13) \\
\hline
\end{tabular}

Note: ${ }^{*}$ indicates significant at the 0.1 level, ${ }^{* *}$ indicates significant at the 0.05 level, ${ }^{* * *}$ indicates significant at the 0.01 level.

\section{Conclusions and Enlightenment}

Small micro-manufacturing industry is to provide new jobs, the main channel, but also the main platform for entrepreneurial growth. Therefore, the healthy development of small micro-manufacturing industry to maintain stable and rapid economic development is of great strategic significance. In this paper, the small micro-manufacturing entrepreneur target groups, the use of theoretical research and empirical research method of combining social capital into small micro-manufacturing entrepreneurial behaviour research frame. The results show that structural capital dimension and relational capital dimension of social capital have positive effects on small and micro manufacturing entrepreneurial behaviours. That is, social capital can promote micro-manufacturing entrepreneurial behaviour.

Therefore, in order to improve small and micro manufacturing entrepreneurial behaviour, on the one hand, entrepreneurs should pay attention to the development and accumulation of social capital, increasing personal social investment, enhance personal image and enhance personal social skills. First, small and micro-enterprise entrepreneurs need to expand social relations, access to peer or potential partners more opportunities for cooperation; Second, small and micro-enterprise entrepreneurs need to promote consensus with others; Third, small and micro enterprises entrepreneurs can join the entrepreneur associations or chambers of commerce to get to know more 
entrepreneurs and industry experts, to establish a diversified social network, which can obtain a richer quality of resources for the survival and development of enterprises. On the other hand, enterprises should constantly update their products and services according to market demand, continuously improve consumer satisfaction, grasp market opportunities, take the lead in using new methods, new technologies and new products, improve product productivity, and reduce production costs.

\section{References}

1. Han Dong-ping, Guo Mei-jia, Deng Xiu-li. The empirical research on the relationship between social capital and credit level of small and medium-sized enterprises. Accounting and Finance, 30: 99-101(2012).

2. W. Stam, T. Elfring, Entrepreneurial orientation and new venter performance: The moderating role of intra and extra industry social capital. Academy of Management Journal, 51(1):97-111(2008).

3. P. Bourdieu. Distinction: A social critique of the judgment of taste.Translated by Rich-and Nice, Roultedge Press, (1994).

4. B.R. Koka, J.E. Prescott. Strategic alliances as social capital: A multimensional view. Strategic Management Journal, 23(9):795-817(2000).

5. QIU Zhong-ning, CHEN Chuan-ming. Effects of internal social capital on organizational performance-based on the perspective of market knowledge transfer, Economic Management, 04: 41-50(2013).

6. H. Westlund. Implications of social capital for business in the knowledge economy: theoretical considerations. In International Forum on Economic Implication of social capital. Tokyo, 2003.

7. Lin Yun, Liu Wei, LI Sui-cheng. Empirical research on the impact of corporate social capital on technological innovation capability. Scientific Management, 01: 35-44(2011).

8. Li Wei, Xu Hui. Study on the relationship between social capital, market knowledge capability and business performance: An analysis from social networks .Soft Science, 10: 93-98(2012).

9. Zhou Ronghua, Zhang Minglin. Analysis on the regulatory effect of entrepreneurial orientation on social capital and small micro-manufacturing entrepreneurial performance. Business Times, 24: 108-109(2014).

10. P. Bourdueu. The forms of capital. In: Richardson G, Handbook of theory and research for the sociology of education[C]. Eestport, CT.: Greed wood Press,. 241-258(1985).

11. J. Liao, H. Welsch. Social capital and entrepreneurial growth aspiration: a comparison of technology - and non - technology based nascent entrepreneurs.Journal of High Technology Management Research: 149-170(2003).

12. D.M.D. Carolis, P. Saparito. Social capital, cognition and entrepreneurial opportunities: a theoretical framewor.Entrepreneur-shin Theory and Practice, 41-56(2006).

13. V. Puhakka. Effects of social capital on the opportunity recognition process.Journal of enterprising culture, 14(2):105-124(2006).

14. W. Tsai, S. Ghoshal. Social capital and value creation: The role of infra-firm networks.Academy of Management Journal, 41:464-476(1998). 